DOI: $10.18522 / 2073-6606-2015-4-83-95$

\title{
MODERN MICROECONOMICS' ROAD TO IRRELEVANCE - WHAT WENT WRONG?
}

EZRA DAVAR,

$\mathrm{PhD}$ in Economics, Independent Researcher,

Netanya, Israel, e-mail: ezra.davar@gmail.com

This paper shows that among the crucial reasons of the modern microeconomic theory's irrelevance to reality is the fact that, unfortunately, it has not been developed since Walras. This paper reveals several crucial differences between Walrasian and post-Walrasian approaches to microeconomic theory:

1. Walras' economic theory is characterized by the evolutionary approach, as it is generally compatible to the human society's development.

2. According to Walras' approach, the demand and supply of goods and services are obtained directly from the solution of models. In the postWalrasian economists' approach the final endowment is directly determined, which prevent discussing employment-unemployment problem in the macro level.

3. Walras' economy is a decentralized economy, which is opposite to the modern general equilibrium theory where the economy is a centralized; and in Walrasian approach each individual is a "price maker»; whilstthe postWalrasian approach, especially the modern approach, views individual rather as a «price taker».

4. Walras used two categories of money: first, the money as commoditynuméraire (measure of value) and its price; and second, money (in circulation and for saving) and its price as the rate of interest. Post-Walrasian economists generally considered only fiat moneyin circulation.

5. According to Walras' micro model for individuals, the budget constraint equation relates to the numéraire (the money as a commodity). Within the post-Walrasian economists' approach, the budget constraint equation relates to the income (or wealth) which is generally given.

Keywords: commodity money; fiat money; microeconomic theory; Walras; modern theory

JEL classifications: $B 3, B 13, C 6, D 5$

(ㄱ) Э. Давар, 2015 


\section{АОРОГА К ИРРЕАЕВАНТНОСТИ: СОВРЕМЕННАЯ МИКРОЭКОНОМИКА. ЧTO ПОШИО НЕ ТАК?}

ЭЗРА ДАВАР,

доктор экономических наук, независимый исследователь,

г. Нетания, Израиль,

e-mail: ezra.davar@gmail.com

В данной работе показано, что одной из важнейших причин неадекватности современной теории микроэкономики реальности является то, что, к сожалению, она не развивалась со времени Вальраса. В статье выявляется несколько важных различий между подходом Вальраса и подходом экономистов поствальрасовского периода к микроэкономической теории:

1. Экономическая теория Вальраса характеризуется эволюционным подходом, который, как правило, совместим с развитием человеческого общества.

2. Согласно подходу Вальраса, спрос и предложение товаров и факторов производства определяются непосредственно при решении модели. В то же время при пост-вальрасианском подходе сначала определяется конечный результат, $u$ только затем - спрос и предложение, а это является препятствием для обсуждения проблем занятости (безработицы) на макроуровне.

3. Экономика Вальраса является децентрализованной, что противоположно современной теории общего равновесия, где экономика является централизованной. Кроме того, в подходе Вальраса каждый индивид является «производителем цен», а не «принимающим цены». При пост-вальрасианском подходе, особенно у современных экономистов, каждый индивид является «принимающим цены».

4. Вальрас рассматривал две категории денег: во-первых, товарные деньги (numéraire) (как меру стоимости) и их цену; во-вторых, деньги как средство обращения и сбережений - их цена эквивалентна процентной ставке. Экономисты пост-Вальраса, как правило, рассматривают только бумажные деньги, находящиеся в обращении.

5. Согласно модели микроэкономики Вальраса для индивидов уравнение бюджетного ограничения относится к товарным деньгам (numéraire). А в подходе экономистов пост-вальрасианского периода уравнение бюджетного ограничения относится к доходу (или благу) и, как правило, задается заранее.

Ключевые слова: товарные деньги; бумажные деньги; теория микроэкономики; Вальрас; современная теория

\section{Introduction}

This paper shows that microeconomics theory has insignificantly advanced and developed since Walras and Walrasian original theory whichwas much more relevant and compatible with the economic reality and hence far superior to the micro models of modern theory.

There is common agreement among economists over microeconomic issues, according to which modern microeconomic theory, as distinguished from macroeconomic theory, is compatible with reality; on the other hand, there are economists who state that «We have concluded that microeconomics does not provide knowledge that could not be obtained 
otherwise and that, as it is usually taught (or presented in textbooks), it encourages an erroneous way of thinking», and «In a word, to understand the real world, one has to forget microeconomics» (Benicourt and Guerrien, 2008. Pp.317, and 322 respectively). However, the theory of microeconomics theory has not been developed from the point of view of money and demand theory.

The economy of individuals is essential in Walras's general equilibrium theory. The process of equilibrium establishment startsfrom the solution of a mathematical model for each individual allowing him/her to obtain the demand and supply for goods and services (including money). First, the mathematical model is uniform for all kinds of agents' economy (Makarov et al., 1995. P. 4). Second, the model of individual's economy illustrates Walras'sevolutionary approach. When Walras' approach is discussed in the post-Walrasian literature, unfortunately, the model of individual's economy is presented either through the exchange economy (in general), or through the production economy (Pareto, 1971; Hicks, 1939; Arrow and Hahn, 1971; Dorfmanetal, 1958; Mas-Colell et al., 1995; Weintraub, 1985; and so on). Moreover, this representation of Walras' model differs from his original model and is incomplete; in its simplified form, it is generally described only as a demander. The offer side is externally given as a total money income (or wealth), when it is assumed that it should be wholly used. Furthermore, if money is integrated, then it is done very artificially, namely, a money commodity is absent as a separate category, which is replaced by money income (Arrow-Hahn, 1971; Debreu, 1959; Patinkin, 1989; Kiyotaki and Wright, 1989; Magill and Quinzii, 1992). Moreover, the offer of money for circulation to the sectors of production is not considered, let alone well-thought-out in the overall theoretical context. Yet, according to the models, the demand and supply of commodities are not directly obtained; they might be indirectly determined by the relationship between the final endowment and the available initial endowment. But, this prevents to discuss problems of employment-unemployment in the modern general equilibrium theory (Davar, 2013; 2014a; 2014b).

Therefore, in this paper, Walras' evolutionary approach will be illuminated and demonstrated by means of the models of the individual economy. The individual economy's model of the Exchange Economy dwells only upon the problems of exchange of consumption's goods. In the Production Economy, the model considers, in addition, the problems of production of the consumption goods by means of factors' services, i.e., three production services are introduced: land capital, personal capital, and fixed capital. In the Capital Formation and Credit Economy the model is further enlarged by the problem of saving and investment. And finally, the last model includes circulating capital and money for it.

In third economy (Capital Formation and Credit) and fourth economy (Circulating Capital and Money), Walras discussed only additional attributes of the economy in question, i.e., micro model is only partly presented by the additional equations. Here, however, it will be presented micro model of Circulating Capital and Money economies,despite of that in post-Walras' economic literature, Walras' micro models, as it was mentioned above, have been generally confined by the Exchange (even by the barter) Economy and sometimes by Production Economy. The micro model of the last economy of Walraswas never formulated; even in the books where Walras' economy is expounded. Morishimachanged Walras' micro model, statedthat 'At first I naturally wanted to reproduce it (Walras's theory of circulation and money - E.D.) in its original form. I tried my best and nevertheless I realized that alterations, some of which would change important characteristics of the model, were inevitable'... 'Walras' theory of money should regarded as an unfinished work, because it is incomplete and obscure in various points and even inconsistent, in that it contains a careless technical slip which has of to be removed' (Morishima, 1977. P. 125), which, unfortunately, is incorrect. Van Daal and Jolink (1993) reproduced Walras' original version of micro models (per se). 
Nevertheless, Walras' micro models of the last two economies are much more compatible with the economic reality and hence far superior tothe micro models of modern theory (vide infra). So, Walras' considerable achievement in the micro theory until today is almost unknown for the commonwealth of learning.

This paper consists of five sections. Following the introduction, the second section considers Walras' individual (Micro) economics model of Circulation and Money Economy. The third section briefly expounds Modern microeconomic theory. Microeconomics textbooks are discussed in the fourth section. Finally, conclusions are presented.

\section{Walras' Micro (individual) model of Circulation and Money Economy}

In this section Walras' two last economies' micro model is presented in one model by two reasons: first, according to Walras' evolutionary approach the attributes of the previousmodel have to be included in the next model; and second, to economize a space of the paper and a time of the future readers.

However, firstly, some specific characteristics of Capital formation and Credit Economy will be discussed. Here the Production economy was extended by the production of new capital goods (investment) and by the creation (formation) of saving. The new capital goods are required for two purposes: the renewal of the old capital goods, which have been destroyed, in order to keep up the existing level of total production, if it is required at all and to expand in line with the new needs. The second component is indicatedby the dynamic element of economics. Therefore, many authors have considered Walras' capital formation theory as a growth theory (Morishima, 1977. Pp. 70-81). However, it is incorrect, because Walras discussed the economy for one period and assumed that the new capital goods were not exploited during this period. By Walras' own words:'... it (the economy - E.D.) remains [for the time being] static because of the fact that the new capital goods play no part in the economy until later in a period subsequent to the one under consideration' (Walras, 1954. P. 283).

Meanwhile, in order to demand (purchase) capital goods, there must be individuals whose incomes exceed their purchase of consumers' goods and services, when the aggregate value of them must be greater than the aggregate value of those which are in the opposite position, i.e. consuming more than their income.

Walras discussed three possibilities as to the relationship between the excess $(e)$ and the amount needed to cover depreciation and insurance: positive, zero and negative.

Walras concluded that only in the third possibility, namely, when positive excess is larger than the amount needed to cover depreciation and insurance, the individual saves. He stated: 'It will be understood that the excess does not constitute true saving unless it is both positive and greater than the sum needed to cover the depreciation and insurance of existing capital goods proper' (Walras, 1954. P. 274). In addition, Walras stated that individuals (capitalists) who createsavings lend them to the entrepreneur demanders for new capital goods, who, in the end of the period of loan, returnthe money with compensation according to the rate of interest (Ibid. P. 270).

In order to convert this new term, a saving, to a term which would be comprehensive, that is, that will be similar to other consumers goods, Walras introduced an abstract (ideal) commodity $(E)$ consisting of perpetual net income with price $p_{e}=1 / i$. This means that each individual has a certain want of commodity $(E)$. So, it is either demanded $\left(d_{e}\right)$ or offered $\left(o_{e}\right)$, as well as other capital services and a quantity of which is obtained by the condition of maximum satisfaction, i.e., by its function of utility $\Phi_{e}\left(q_{e}\right)$.

So, Walras' micro model of Capital Formation and Credit economy differs from the model of the Production Economy by introducing the new commodity $(E)$ for consumption, and accordingly, its utility function and its price $\left(p_{e}\right)$ and the differentiation and detailedperformance of the fixed capital.

Circulation and Money is Walras' final economy. Until today, in our opinion, it is a peerless achievement in economic science (see Schumpeter). In this stage Walras extended 
the previous three economies (Exchange, Production, and Capital Formation and Credit) by the circulation capital goods, raw materials and money for circulation. Walras assumed that products for final using and raw materials 'be the same products and raw materials, however, as circulating capital goods, that it to say, as goods rendering a service of availability either in the larders and cupboards of consumers or in storerooms and salesrooms of producers' (Walras, 1954. P. 319).

Walras stated, therefore, that for sake of conducting a normal life each individual is in need of a store of certain quantities of products, on the one hand, and to save financial resources for the future, on the other hand (Walras, 1954. P. 317).

Yet, Walras also assumed that in order that a process of production would be effective, every firm must-needs to have a store of produced products and raw materials and possibilities to carry out required operations in the markets, i.e. it needs sufficient money resources (Ibid. P. 318).

From the point of view of the individual, this means that theindividual needs additional services of products in addition to consumption, quantities of which are determined on the basis of their initial available quantities and the utility functions for their services, so that to achieve a maximum rate of satisfaction. In other words, each individual, in addition to the previous economies, formulates utility functions for each product for circulation $\Phi_{i^{\prime}}\left(q_{i^{\prime}}\right)$ and determines its initial available quantities $q_{i^{*}}$. And, the quantities that are either offered $\left(o_{i^{\prime}}\right)$ or demanded $\left(d_{i^{\prime}}\right)$ (van Daal and Jolink, 1993. P. 177) at certain prices $\left(p_{i^{\prime}}\right)$ would be obtained as well as products for consumption. Yet, secondly, to satisfy the services of circulation capital goods' availability, each individual needs money for each of them separately. So, each individual, additionally, formulates the utility functions of every circulation of capital goods in money terms $\Phi_{\mathrm{i}^{\prime \prime}}\left(q_{i^{\prime \prime}}\right)$ and the quantities demanded $\left(x_{i^{\prime \prime}}\right)$ at the same prices as for the circulation of capital goods, will obtained similarly (see above). By means of these obtained quantities of money and the initial available quantity of money $q$ for each individual, we might determine either offer or demand for money (vide infra) forcirculation into production. Finally, as regards raw material, Walras stated that, 'inasmuch as consumers do not have any use for raw materials, the quantities they effectively offer will be equal to the total quantities they possess $q^{m} \ldots$ and, consequently, the total effective offer equal the total existing quantities, $Q^{m} \ldots{ }^{\prime}$ (Walras, 1954. P. 320). This means that individual offers his available quantities of raw materials at a price that takes under consideration the whole picture, i.e., the existing (available) quantities of the raw materials, as well as the existing (available) money for circulation, are wholly offered and consequently, in equilibrium state, they should be wholly demanded (vide infra). This means that there is a second type of market clearing's concept, where effective demand that is equal to the available quantity, for money (in circulation) and raw materials; hence, the latter are entirely used. This type is distinguished from the first type of market clearing's concept, where the effective demand is equal to effective supply, for the commodities and the services; and they are less or equal to the available quantity; hence, commodities might be unsold and services might be unemployed (vide supra).

Now, each individual's model for circulation and money economy might be formulated as:

subject to

$$
\begin{gathered}
\text { maximize } \sum_{i=1}^{m} \Phi_{i}\left(x_{i}\right)+\sum_{j=1}^{t} \Phi_{j}^{t}\left(y_{j}^{t}\right)+\sum_{j=1}^{p} \Phi_{j}^{p}\left(y_{j}^{p}\right)+\sum_{j=1}^{l} \Phi_{j}^{k}\left(y_{j}^{k}\right)+\Phi_{e}\left(x_{e}\right)+ \\
+\sum_{i^{\prime}=1}^{m} \Phi_{i^{\prime}}\left(x_{i}\right)+\sum_{i^{n}=1}^{m} \Phi_{i^{\prime}}\left(x_{i^{\prime}}\right)+\Phi_{e^{\prime}}\left(x_{e^{\prime}}\right),
\end{gathered}
$$

$$
\begin{array}{ll}
y_{j}^{t}-d_{j}^{t}+o_{j}^{t}=q_{j}^{t}, & (j=1,2, \ldots, t), \\
y_{j}^{p}-d_{j}^{p}+o_{j}^{p}=q_{j}^{p}, & (j=1,2, \ldots, p), \\
y_{j}^{k}-d_{j}^{k}+o_{j}^{k}=q_{j}^{k}, & (j=1,2, \ldots, l), \\
x_{i^{\prime}}-d_{i^{\prime}}+o_{i^{\prime}}=q_{i^{\prime}}, & (i=1,2, \ldots, m),
\end{array}
$$




$$
\begin{gathered}
o_{u} p_{u^{\prime}}=q_{u} p_{u^{\prime}}-\sum_{i^{\prime}=1}^{m} x_{i^{\prime}} p_{i^{\prime}}-x_{e^{\prime}} p_{e^{\prime}} \\
x_{e}-d_{e}+o_{e}=q_{e}, \\
x_{1}+\sum_{i=2}^{m} x_{i} p_{i}-\sum_{j=1}^{t} o_{j}^{t} p_{j}^{t}+\sum_{j=1}^{t} d_{j}^{t} p_{j}^{t}-\sum_{j=1}^{p} o_{j}^{p} p_{j}^{p}+\sum_{j=1}^{p} d_{j}^{p} p_{j}^{p}-\sum_{j=1}^{l} o_{j}^{k} p_{j}^{k}+ \\
+\sum_{j=1}^{l} d_{j}^{k} p_{j}^{k}-o_{e} p_{e}+d_{e} p_{e}-\sum_{i=1}^{m} o_{i^{\prime}} p_{i^{\prime}}+\sum_{i=1}^{m} d_{i^{\prime}} p_{i^{\prime}}+\sum_{i=1}^{m} x_{i^{\prime \prime}} p_{i^{\prime \prime}}-q_{u} p_{u^{\prime}}- \\
-\sum_{s=1}^{S} q_{s}^{m} p_{s}^{m}+x_{e^{\prime}} p_{e^{\prime}}=0, \\
x_{1}, x_{i^{\prime}} y_{j^{\prime}} x_{e^{\prime},}, d_{j}, x_{i^{\prime}}, x_{i^{\prime}}, o_{i^{\prime}}, d_{i^{\prime}}, \text { and } o_{j} \geq 0,(i=2,3, \ldots, m ; j=1,2, \ldots, n)
\end{gathered}
$$

Where

$p_{i}, p_{i}, p_{e}, p_{i}, p_{i, n}, p_{s}^{m}, p_{u}, p_{u^{\prime}}, p_{e^{\prime}}-$ is the offer price of goods, of services, of net income, of circulating capital goods, of circulating capital goods in monetary terms, price of raw materials in circulation, price of numéraire, price of money, and price of net income in monetary commodity terms, respectively;

$x_{i}, y_{i}^{t}, x_{i,}, x_{e},-$ is the quantity of goods for consumption which finally remains at the individual's, and for services, circulating capital goods in monetary terms, and for net income in monetary terms, respectively;

$d_{i}, o_{i}, d_{i}, o_{i}, d_{e}, d_{u^{\prime}}$, is the demand or offer of services $j$; or the demand or offer of the circulating capital goods; or the demand of net income; and the demand of money in circulation, respectively; and it is equal either to $\left(q_{j}+d_{j}\right)$ or $\left(q_{j}-o_{j}\right)$;

The model (2-1)-(2-9) is extended version of the model of Capital Formation and Credit; namely, relevant equations are extended by according components for circulation capital goods and money. And there are $m+1$ new equations: $m$ equations (2-5), which assumes that offered quantities of circulation capital goods are bounded by their available quantities for each certain individual and one equation (2-6), which determines offered quantities of money for circulation are assumes that it is bounded by its available quantity.

It follows from the structure of the model that if either offer $o_{i}$ or demand $d_{i}$ is positive, the other would equal zero; as both have the same price and both influence the utility functions indirectly by the final endowment $x_{i}$ (Hiller and Lieberman, 1995. Pp. 586-591). In other words, a certain commodity cannot be offered and demanded simultaneously by the same individual. In addition, the offered quantities of each commodity are bounded by the holding quantities (condition (2-2)-(2-7), when the demand quantities are bounded by the holding quantities of all commodities, i.e., by the budget constrains (condition $(2-8)$ ). Therefore, the magnitude for demand (or offer) is a function of prices, available quantities and parameters of utility.

The conditions of maximum satisfaction also spread at circulation capital goods not only in kind but also in money and their forms are:

$$
\begin{array}{ll}
\varphi_{i^{\prime}}\left(x_{i^{\prime}}\right)=p_{i^{\prime}} \varphi_{1}\left(x_{1}\right), & (i '=1,2, \ldots, m) \\
\varphi_{i^{\prime}},\left(x_{i^{\prime}}\right)=p_{i^{\prime}}, \varphi_{1}\left(x_{1}\right), & (i ’=1,2, \ldots, m) \\
\varphi_{e^{\prime}}\left(x_{e^{\prime}}\right)=p_{1}, \varphi_{1}\left(x_{1}\right), &
\end{array}
$$

The complete derived demand (supply) function of products (services) is obtained on the basis of an individual model for Circulation and Money economy must include the following additional parameters, and as connected to the derived demand function of Capital Formation and Credit: the available quantity of the circulation capital goods $\left(q_{i}\right)$, their prices $\left(p_{i}\right)$, and the parameter of their utility function $\left(\varphi_{i}\right)$; the available quantities of raw materials $\left(q_{s}^{m}\right)$ and their prices $\left(p_{s}^{m}\right)$; the available quantity of money for circulation $\left(q_{u}\right)$, its price $\left(p_{u}\right)$ and parameters of the utility functions of circulating products in money $\left(\varphi_{i}{ }^{\prime}\right)$ included commodity $(E)$. This is:

$$
\begin{aligned}
& d=f\left(p_{2}, p_{3}, \ldots, p_{m^{\prime}} ; p_{1}^{t}, p_{2}^{t}, \ldots, p_{t}^{t} ; p_{1}^{p}, p_{2}^{p}, \ldots, p_{p}^{p} ; p_{1}^{k}, p_{2}^{k}, \ldots, p_{l}^{k} ; p_{e} ; p_{1^{\prime}}, p_{2^{\prime}}, \ldots, p_{m^{\prime}} ;\right. \\
& p_{1^{\prime}}^{m}, p_{2^{\prime}}^{m}, \ldots, p_{s^{\prime}}^{m} ; p_{u^{\prime}} ; q_{1}^{t}, q_{2}^{t}, \ldots, q_{t}^{t} ; q_{1}^{p}, q_{2}^{p}, \ldots, q_{p}^{p} ; q_{1}^{k}, q_{2}^{k}, \ldots, q_{l}^{k} ; q_{e} ; q_{1}, q_{2^{\prime}}, \ldots, q_{m^{\prime}} ; \\
& \quad q_{1^{\prime}}^{m}, q_{2^{\prime}}^{m}, \ldots, q_{s^{\prime}}^{m} ; q_{u} ; \varphi_{1}, \ldots, \varphi_{m} ; \varphi_{1}^{t}, \ldots, \varphi_{t}^{t} ; \varphi_{1}^{p}, \ldots, \varphi_{p}^{p} ; \varphi_{1}^{k}, \ldots, \varphi_{l}^{k}, \varphi_{1^{\prime}}, \ldots, \varphi_{m} ; \\
& \left.\quad \varphi_{1^{\prime}, \ldots,}, \ldots, \varphi_{m^{\prime},} ; \varphi_{e} ; \varphi_{e^{\prime}}\right) ;
\end{aligned}
$$


Where, for the sake of simplicity, we use $d$ to express a common notation for demand and supply functions for all kinds of commodities and services.

Walras's version of a derived demand function for Circulation and Money,then, has to be also an extended version of the Capital Formation and Credit Economy. This means that according to Walras's approach the derived demand function has the following form

$$
d=f\left(p_{2}, p_{3}, \ldots, p_{m} ; p_{1}^{t}, p_{2}^{t}, \ldots, p_{t}^{t} ; p_{1}^{p}, p_{2}^{p}, \ldots, p_{p}^{p} ; p_{1}^{k}, p_{2}^{k}, \ldots, p_{l}^{k} ; p_{e^{\prime}} ;\right.
$$

$\left.p_{1^{\prime}}, p_{2^{\prime}}, \ldots, p_{m^{\prime}} ; p_{1^{\prime}}^{m}, p_{2^{\prime}}^{m}, \ldots, p_{s^{\prime}}^{m} ; p_{u^{\prime}} ;\right)$;

While individual's demand of the numéraire product (1) is obtained by the equation

$$
\begin{gathered}
x_{1}=-\sum_{i=2}^{m} x_{i} p_{i}+\sum_{j=1}^{t} o_{j}^{t} p_{j}^{t}-\sum_{j=1}^{t} d_{j}^{t} p_{j}^{t}+\sum_{j=1}^{p} o_{j}^{p} p_{j}^{p}- \\
-\sum_{j=1}^{p} d_{j}^{p} p_{j}^{p}+\sum_{j=1}^{l} o_{j}^{k} p_{j}^{k}-\sum_{j=1}^{l} d_{j}^{k} p_{j}^{k}+\sum_{j=1}^{l} o_{j}^{l} p_{j}^{l}-\sum_{j=1}^{l} d_{j}^{l} p_{j}^{l}+ \\
+o_{e} p_{e}-d_{e} p_{e}+\sum_{i=1}^{m} o_{i}, p_{i^{\prime}}, \sum_{i=1}^{m} d_{i^{\prime}} p_{i^{\prime}}-\sum_{i=1}^{m} x_{i,} p_{i^{\prime}}+q_{u} p_{u^{\prime}}+\sum_{s=1}^{S} q_{s}^{m} p_{s}^{m}-x_{e^{c}} p_{e^{\prime},},
\end{gathered}
$$

Yet, by means of such results for all the individuals in question, we can determine in addition to the previous economy the total offer of each circulation capital goods' services and money for circulation in production, which are obtained as the difference between total offer and total demand for individuals' consumption for the circulation capital goods; and as the difference between the available quantities of money and its total demand for individuals, respectively.

\section{Modern Microeconomic Theory}

It is convenient that the modern microeconomic theory has been compatible with reality rather than with macroeconomic theory. However, since Walras, unfortunately, microeconomics theory has not developed from the point of view of money theory and has insignificantly developed from the point of view of demand theory. Microeconomic models are generally confined by the Exchange and sometimes Production Economies, and if money is integrated, then it is done superficially. In these models demand and supply of commodities might be indirectly determined by the relationship between the final endowment and the available initial endowment, but it is not done.

Let us to elucidate our above mentioned argumentation using the well-known and sole paper of Clower (1967) 'A Reconsideration of the Microfoundations of Monetary Theory'. Clower states that 'Modern attempts to erect a general theory of money and prices on Walrasian foundations (Lange, Patinkin, Hicks, and Samuelson) have produced a model of economic phenomena that is suspiciously reminiscent of the Classical theory of barter economy. My purpose in this paper is to show that the conception of money economy implicit in these constructions is empirically and analytically vacuous, propose an alternative microfoundation for the pure theory of a money economy' (Clower, 1967. P. 81).

Here Clower has identified post-Walras theory of money with Walras's theory, such that if the modern theory is incorrect then the same is true for Walras's theory. However, fortunately, this statement of Clower and other authors is generally mistaken (vide infra). This is a clear example how the modern authors' blaming Walras's theory due to incorrect theories by other modern economists.

Clower, first, discusses the micro model of the modern authors:

By hypothesis, market excess demands are defined in terms of individual demand functions for goods and money obtained as solutions to the decision problem:

Maximize

$$
U_{j}\left(d_{1 j}, \ldots, d_{n j}, M_{j} P\right)
$$

Subject to

$$
\sum_{i=1}^{i=n} p_{i}\left(d_{i j}-s_{i j}\right)+M_{j}-\underline{M}_{j}=0,
$$

Where $U_{j}$ satisfies familiar continuity and curvature conditions, $s_{i j}$ and $d_{i j}$ represent initial and desired quantities of goods, $\underline{M}_{j}$ and $M_{j}$ represent initial and desired quantities of fiat money, and $P$ is a fixed weight index of the money prices $p_{1}, \ldots, p_{n}$ ' (Clower, 1967. P. 82). 
This model differs from Walras's model of individual's economy in Exchange economy: first, Walras used fiat money only in the last economy - Circulation and Money - for the circulation only, side by side with the money commodity, which in the previous three economies is served as money. Second, fiat money is valueless and useless; therefore, it has no utility and cannot appear in the utility function. Samuelson, in the same way, wrote: 'If, however, one does put $M$ directly into $U$, one must remember the crucial fact that $M$ differs from every other good (such as tea) in that it is not really wanted for its own sake but only for the ultimate exchanges it will make possible. So along with $M$, we must always put all $P_{s}$ into $U$, so that $U$ is homogeneous of degree zero in the set of monetary variables $\left(M, P_{1}, \ldots, P_{m}\right)$ with the result that $\left(\lambda M, \lambda P_{1}, \ldots, \lambda P_{m}\right)$ leads to the same $U$ for all $\lambda$ ' (Samuelson, 1968. $P$. 8). Third, Walras manipulated the demand and supply of all categories, later obtaining the final endowment by their means. Clower and consequently Hicks, Lange, and Patinkin use initial and final endowment, which allows calculating demand and supply. Finally, the utility function includes all components (commodities, prices, money) simultaneously, which from the practical point of view is problematic, if not impossible;while Walras considered utility function for each good separately.

Clower states that the conclusion in the discussing model 'indicates that money plays no distinctive role in economic activity' (Ibid. P. 83). Therefore, he suggests using the money commodity and assumes: 'I shall restrict attention in the argument that follows to pure money economics in which one and only one commodity can be traded directly for any other commodity' (Ibid. P. 85). Then, he presents his own, alternative model where there is 'a clear separation between goods demanded for purchase (offers to sell money) and goods offered for sale (offers to buy money)' (Ibid. P. 86). The result is that the budget constraint equation is divided into two constraints: (a) a constraint on money expenditure and (b) a constraint on money income'. So, the model is

$$
U_{j}\left(d_{1 j}, \ldots, d_{n j}, M_{j} / P, m_{j} / P\right)
$$

$$
\begin{aligned}
& \sum_{\substack{i=1 \\
i=n}}^{i=n} P_{i} x_{i j}+M_{j}-\underline{M}_{j}=0, \quad x_{i j}=d_{i j}-s_{i j}, \quad x_{i j} \geq 0 \\
& \sum_{i=1}^{i=n} P_{i} x_{i j}+m_{j}=0, \quad x_{i j}<0
\end{aligned}
$$

where $m_{j}$ represents desired "intra-period" receipts of money income' (Ibid. Pp. 87-88).

Such a division is artificial and incompatible with reality, because in practice expenditure and income are mutually connected. So, Clower's statement that 'the total value of goods demanded cannot be in any circumstancesexceed the amount of money held by the transactor at the outlet of the period' (Ibid. P. 87) is doubtful. For this purpose, suppose that an individual does not hold any initial amount of money, so he cannot demand any goods, instead of which he might have income? Clower continues, 'I shall refer henceforth to $m_{j}$ as the income demand for money, to $M$ as the reservation demand for money. Such a separation of income and reservation demands has no place in accepted equilibrium models,' (Clower, 1967. P. 87). This statement of Clower is correct in the relation to models of post-Walras's authors; however, it is incorrect in relation to Walras's model. The micro model for an individual of Walras' last economy includes not only the reservation - demand for money (demand for the money commodity) and the income demand for money (saving), but also the supply of money to production for circulation (vide supra).

The result is that as Clower states, 'Unlike established theory, moreover, a change initial money balances has no "income" effect on goods offered for sale. More significantly, changes in initial endowments of goods have no "income" effect on commodities that are demanded for purchase; i.e., supply of goods does not create demand for other goods. All of these results are obvious consequences of dichotomizing budget constraint into sepa- 
rate expenditure and income branches', (Clower, 1967. P. 88) which means that this Walras' model is incompatible with reality (Davar, 2011; 2012).

Moreover, Clower also states that 'As in established theory, the money value of the sum of all excess demands, including the excess demand for reservation balances and for money income, is identically zero; hence a proposition analogous to what has come to be known as Walras' Law applies to transactor in a money as well as to transactor in a barter economy' (Ibid.). This means that his approach also represents disequilibrium state similar post-Walras's economists approach (vide supra) because it is based on the "Walras' Law" formulated by Lange.

Finally, and more importantly, Clower does not discuss the connection (relationship) between micro and macroeconomics.

In addition, it is ironic that Baumol, who has been claiming that Walras's mathematics is primitive, has created a much poorer model, and this writing more than a century after Walras. Baumol writes 'Then, using obvious notation, equilibrium requires

(1) $\operatorname{Max} \Sigma \mathrm{p}_{\mathrm{i}} \mathrm{y}_{\mathrm{i}}-\mathrm{C}\left(\mathrm{y}_{1}, \ldots, \mathrm{y}_{\mathrm{n}}\right)$

Subject to (2) $\Sigma \mathrm{p}_{\mathrm{i}} \mathrm{y}_{\mathrm{i}}-\mathrm{C}\left(\mathrm{y}_{1}, \ldots, \mathrm{y}_{\mathrm{n}}\right) \leq \mathrm{k}$ (where we will select $\mathrm{k}=0$ )' (Baumol, 2007. P. 15).

In regards to micro model in the modern general equilibrium theory, through a careful consideration of the relevant part of the complete Arrow-Debreu model (Arrow and Hahn, 1971; Mas-Colleletal, 1995), we can conclude they are formally identical, despite the fact that Walras considered an individual economy, while Arrow-Debreu discussed a household economy. At the same time, there are several differences, since all above claiming about Clower's micro model is relevant.

First, the Arrow-Debreu utility function included all goods and services together in one function, which from the practical point of view is problematic, if not impossible.

Secondly, either the demand or the offer of a certain good or capital service in Walras's approach is obtained by direct conditions; this means that their quantities are obtained for concrete price systems for services and products. In the Arrow-Debreu approach, they are determined implicitly. Therefore, there exists an illusion as if the whole existing quantity is traded, which prevents to discuss problem of employment-unemployment.

Thirdly, in the Arrow-Debreu micro model money is generally disappeared.

Fourthly, prices in the Arrow-Debreu micro model are unknowns, while according to Walras's approach they are given.

Finally, the Arrow-Debreu approach does not consider the problem of saving-investment.

At the same time, there are some novel features in the modern approach. First, the consumption and production is divided; but the structure of their models is similar and yet, all entrepreneurs are included in one model together with all households, something that makes such an approach very doubtful and unrealistic. Secondly, in the budget constraint of the modern approach there is an additional component of income from profits of production sector that is the individual's share. However, if we take into account the fact that some prices of goods and services might be zero in general equilibrium states, its usefulness is negligible.

\section{Microeconomics Textbooks}

Let us satisfy ourselves by discussing only of the advanced Microeconomic textbook (Mas-Colell et al., 1995; see also Varian, 2010). In Chapter 3 Classical Demand Theory they write:

The consumer's problem of choosing her most preferred consumption bundle given prices $p>0$ and wealth level $w>0$ can now be stated as the following utility maximization problem (UMP):

$\operatorname{Max} u(x)$

$x \geq 0$

s.t. $p \cdot x=w($ Mas-Colell et al., 1995. P. 50). 
All flaws of the modern microeconomic model from the previous section are relevant for this model too, namely:

(1) The utility function included all goods and services together in one function, which from the practical point of view is problematic, if not impossible.

(2) In this model the unknown are final endowment.

(3) In this model the budget constraint equation relates to the wealth which is vaguely determined and it is given.

(4) Such attributes as primary factors of production; money commodity, money for circulation, saving, and so on, is absent.

In addition they assume:

Then the Walrasian demand correspondence $x(p, w)$ possesses the following properties:

(i) Homogeneity of degree zero in $(p, w): x(\alpha p, \alpha w)=x(p, w)$ for any $p, w$ and scalar $\alpha>0$.

(ii) Walras' law: $p \cdot x=w$ for all $x=x(p, w)$.

(iii) Convexity/uniqueness: ... (Ibid. P. 52).

It is very difficult to understand these properties from an economic perspective. First, homogeneous function is 'very special case' (Allen, 1960. P. 315). Second, in general, it destroys fundamental postulate of economics, namely, the connection between prices and quantities.

Second property is explained as

(ii) Walras' law follows from local nonsatiation. If $p \cdot x<w$ for some $x \in x(p, w)$, then there must exists another consumption bundle $y$ sufficiently close to $x$ with both $p \cdot y<w$ and $y>x \ldots$. But this would contradict $x$ being optimal in the UMP' (Ibid. P. 52).

Walras's Law has been playing crucial role to prove of equilibrium existence (see: Arrow, 1989). However, question is what kind of Walras's Law is discussed? Walras's Law using in the equilibrium existence by modern authors (Arrow-Debreu, Mackenzie) differs essentially from Walras's original laws formulated by Walras himself (Davar, 1994; $2002 ; 2012)$. Moreover, it differs also from initial Walras' Law formulated by Lange ( $\mathrm{Da}$ var, 2012; 2014b).

Finally and most importantly, what is presented here as Walras' law, in the case of Walras it is an attribute of his model, as well as in this model; hence it is not formulated as a law, i.e., it is ordinary constrain. Moreover, this law differ not only Walras's original laws but also from "Walras' law" formulated by post-Walras economist, and also using in this textbook (Mas-Collelet al., 1995. P. 582).

Beforehand in the Chapter 2 Consumer Choice they state:

Walras's law says that the consumer fully expends his wealth. Intuitively, this is a reasonable assumption to make as long as there is good that is clearly desirable. Walras's law should be understood broadly: the consumer's budget may be an intertemporal one allowing for savings today to be used for purchases tomorrow. What Walras's law says is that the consumer fully expends his resources over his lifetime' (Ibid. P. 23).

What is the meaning of "resources over his lifetime"? What is its measurement? Is this what Walras' law says!?

Hence, in an economy where savings, investment and money play a leading role, as distinguished from the modern economic theory, these properties might be irrelevant, at least problematic.

To sum up, we can conclude that instead of a formal identity, significant differences exist in their approaches to the individual economy, which illustrates that the micro theory has was insignificantly advanced and developed since Walras.

\section{Conclusions}

This paper shows that the theory of microeconomics, unfortunately, has not developed since Walras and is irrelevant to the economic realty. This paper reveals the several crucial differences between Walrasian and post-Walrasian approaches to microeconomic theory: 
1. Walrasian economic theory is characterized by the evolutionary approach, as it is generally compatible to the human society's development. Walras discussed micro model for four economies, and final economy's - Circulation and Money - micro model, until today, in our opinion, is a peerless achievement in economic science. While, in the postWalrasian economists' approach if money is integrated, then it is done very artificially, namely, a money commodity is absent as a separate category, which is replaced by fiat and presented as money income or wealth.

2. According to Walrasian approach, the demand and supply of goods and services are obtained directly from the solution of models. The offered quantity of a certain good (service) must be less or equal to its available quantity. In the post-Walras's economists' approach the final endowment is directly determinedfor all commodities and their sum is equal to the sum of their initial endowment; which prevent discussing employmentunemployment problem in the macro level.

3. Walrasian economy is a decentralized economy, where individuals organize their economic life, which is opposite to the modern general equilibrium theory wherethe economy is a centralized; and in Walras's approach each individual is "price maker"; whilstthe postWalrasian approach, especially the modern approach is "price taker".

4. According to Walras' micro model for individuals, the budget constraint equation relates to the numéraire (the money commodity), which shows that either the offer or the demand of the money commodity (numéraire) depends on the balance between the total value of demand and the total value of offer of the commodities not used as the numéraire. By post-Walras's economists' approach, the budget constraint equation relates to the income (or wealth) which is generally vaguely determined and it is given; and the demand of money is equal to the total offer of all other commodities and its offer, is equal to the total demand of all other commodities.

5. Walras, in his approach, used two types of demand functions: the first one is that where the demand quantity of a certain commodity depends only on its price and conversely; i.e., the original (ordinary) demand function (curve) $-\left(d_{i}=f_{i}\left(p_{i}\right)\right.$, and $\left(p_{i}=\varphi_{i}\left(d_{i}\right)\right)$; and second is the demand (offer) quantity of any commodity (service) depends on the prices of all commodities and it is obtained by the solution of the micro model; i.e., the derived (general) demand function - for an exchange economy $-\left(d_{i}=f_{i}\left(p_{2}, p_{3}, \ldots, p_{m}\right)\right)$. This is also the same for the supply of commodities (services). Post-Walras's economists, unfortunately, either did not make such a differentiation of functions or if they did, then it is incomplete and only for the demand.

6. According to Walras' approach, there is a separable utility function, whilst in the model of the modern economy the utility function included all goods and services together in one function, which from the practical point of view is problematic, if not impossible.

7. In the final money economy, Walras used two categories of money: first, the money commodity-numéraire (measure of value); and second, money (in circulation and for saving); and stressed that they have different roles and different prices. Post-Walras's economists generally did not make such a differentiation of money and they considered only one category of money - fiat money.

8. Textbooks of microeconomics have to be rewritten, consequently reformulating micro theory.

\section{REFERENCES/ЛИTEPATУPA}

Allen R.D. (1960). Mathematical Economics. London: MacMillan.

Arrow K.J. and Hahn F.H. (1971). General Competitive Analysis. San Francisco: HoldenDay, Inc.

Baumol W. (2007). Entrepreneurship and Innovation: The (Micro) Theory of Price and Profit, File: Entpricetheory-w-apr-4-2007.

Baumol W.J. and Goldfeld S.M. (eds.) (1968). Precursors in Mathematical Economics: An Anthology. London School of Economics. 
Benicourt E. and Guerrien B. (2008). Is Anything Worth Keeping in Microeconomics? // Review of Radical Political Economics, vol. 40, no. 3, pp. 317-323.

Clower R.W. (1967). A Reconsideration of the Microfoundations of Monetary Theory // Western Economic Journal, 6(1), pp. 1-8.

Davar E. (1994). The Renewal of Classical General Equilibrium Theory and Complete Input-Output System Models. Avebury, Aldershot, Brookfield USA, Hong Kong, Singapore, Sydney.

Davar E. (2002). Mainstream Mathematical Economics in the 20th Century: by Nicola, P.C. // European Journal of Political Economy, 18(2), pp. 401-404.

Davar E. (2011). Flaws of Modern Economic Theory: The Origins of the Contemporary Financial-Economic Crisis // Modern Economy, 2, 25-30.

Davar E. (2012). Is 'Walras' Law' Really Walras's Original Law? // World Review of Political Economy, vol. 3, no. 4, pp. 478-500.

Davar E. (2013). Input-Output Analysis and Contemporary Economics. LAP Lambert Academic Publisher.

Davar E. (2014a). How Flaws in the General Theory Render It Irrelevant to the Real World // Modern Economy, vol. 5, no. 1, pp. 93-104.

Davar E. (2014b). Walras and Contemporary Financial-Economic Crisis // Modern Economy, vol. 5, no. 5, pp. 635-656.

Debreu G. (1959). Theory of Value. New York: Wiley.

Dorfman R., Samuelson A.P. and Solow R.M. (1958). Linear Programming and Economic Analysis. New York: McGraw-Hill Book Company, Inc.

Hicks J.R. (1934). Leon Walras // Econometrica, vol. 2, no. 4, pp. 338-348.

Hicks J.R. (1939-1946). Value and Capital. Oxford: Clarendon Press.

Hicks J.R. (1983). Classics and Moderns. Oxford: Basil Blackwell.

Hiller F.S. and Lieberman G.J. (1995). Introduction to Operation Research. McGraw-Hill, Inc. Jaffé W. (1954). Translator's Foreword / In: Walras L. Elements of Pure Economics. London: Allen and Unwin.

Jaffé W. (1980). Walras's economics as other see it // Journal of Economic Literature, 18, pp. 528-549, reprinted in: Walker D.A. (1983). William Jaffe's Essays on Walras. New York, Cambridge: Cambridge University Press.

Kiyotaki N. and Wright R. (1989). On Money as a Medium of Exchange, Journal of

Political Economy, vol. 97, no. 41, 927-954.

Magill M. and Quinzii M. (1992). Real effects of money in general equilibrium // Journal of Mathematical Economics, 21, pp. 301-342.

Makarov V.L., Levin M.J. and Rubinov A.M. (1995) Mathematical Economic Theory. New

York, Amsterdam: Elsevier/North-Holland.

Mas-Colell A., Whinston M.D. and Green J.R. (1995). Microeconomic Theory. New York:

Oxford University Press.

Morishima M. (1977). Walras' Economics: A pure theory of capital and money. Cambridge,

New York: Cambridge Univ. Press.

Pareto V. (1968). Mathematical Economics / In: Baumol W.J. and Goldfeld S.M. (eds.)

Precursors in Mathematical Economics: An Anthology, London School of Economics.

Pareto V. (1971). Manual of Political Economy. Macmillan.

Patinkin D. (1989). Money, Interest, and Prices. Cambridge, Massachusetts Abridged:

The MIT Press.

Samuelson P.A. (1947). Foundations of Economic Analysis. Cambridge: Harvard

University Press.

Samuelson P.A. (1968). What Classical and Neoclassical Monetary Theory Really was //

The Canadian Journal of Economics, vol. 1, no. 1, pp. 1-15.

Schumpeter J.A. (1954). History of Economic Analysis. New York: Oxford University Press. 
Smith A. (1937). The Wealth of Nations. Random House., Inc.

Van Daal J. (2005). Introduction / In: Walras L. (2005).Studies in Applied Economics Theory of the Production of Social Wealth, in 2 vols. London: Routledge.

Van Daal J. and Jolink A.(1993). The Equilibrium Economics of Leon Walras. New York: Routledge.

Varian H.R. (2010). Microeconomics Intermediate. New York: W.W. Norton \& Company. Walker D. (1996). Walras's Market Models. Cambridge: Cambridge University Press.

Walker D.A. (1983). William Jaffe's Essays on Walras. New York, Cambridge: Cambridge University Press.

Walker D.A. (2006). Walrasian Economics. New York, Cambridge: Cambridge UP.

Walras L. (1954). Elementsof Pure Economics. London: Allen and Unwin.

Walras L. (2005). Studies in Applied Economics Theory of the Production of Social Wealth, in 2 vols. London: Routledge.

Weintraub E.R. (1985). General Equilibrium Analysis: Studies in Appraisal. Cambridge: Cambridge University Press. 